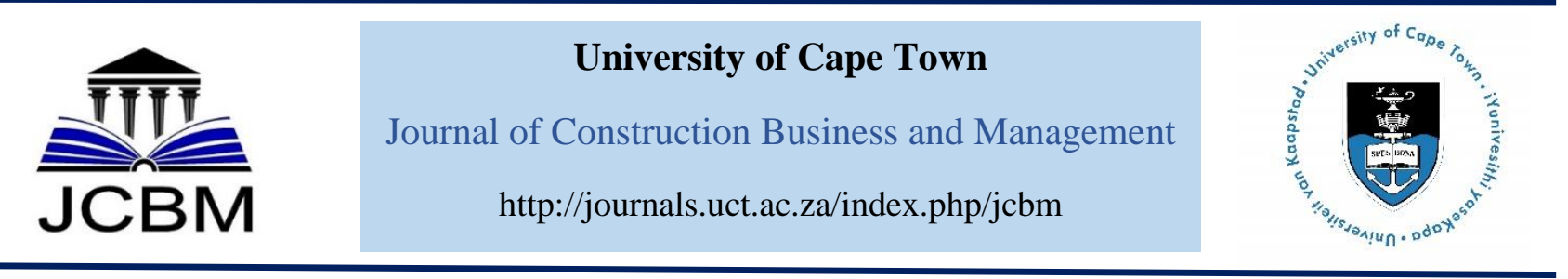

\title{
Effectiveness of Mechanisms for Enforcement of Ethical Standards in the Construction Industry
}

\author{
B.F. Akintola ${ }^{1}$, G.O. Jagboro ${ }^{2}$, G.K. Ojo ${ }^{3}$ and S.J. Odediran ${ }^{4}$ \\ ${ }_{1,2,3 \& 4}^{4}$ Department of Quantity Surveying, Obafemi Awolowo University, Ile-Ife, Nigeria
}

Received 5 February 2018; received in revised form 1 February 2019, 25 March 2019 and 3 July 2019; accepted 15 July 2019. https://doi.org/10.15641/jcbm.4.1.530

\begin{abstract}
Gross unethical conducts are common issues among professionals in the construction sector due to the heterogeneous nature of the industry. However, limited efforts are made to ensure that ethical standards become enforced among professionals in the sector. Therefore, this study assessed effective mechanisms for the enforcement of ethical standards to improve public confidence in construction professionals. Data were collected through copies of questionnaire administered on professionals in consultancy, contracting and government organizations in Southwestern Nigeria. One hundred and seventy-two (172) copies of questionnaire were retrieved and found suitable for the analysis. Data collected was analyzed using both the descriptive and inferential statistics. The study revealed that all the ethical standards identified were moderately significant with relative effective index (REI) that ranged from 0.585 to 0.526 . Some of these included personal reputation, promotion of civic right, good citizenry, among others. Four major effective mechanisms for the enforcement of ethical standards extracted through factor analysis are the roles to be played by the stakeholders $(68.22 \%)$, individual (9.44\%), industry $(3.64 \%)$ and legal instruments $(3.08 \%)$. It was concluded that these four mechanisms are effective in the enforcement of ethical standards in the construction industry. The study recommends that all construction stakeholders must ensure that all hands are on deck through collaborations to sanitise the image of the industry. The outcome of this research will improve the ethical orientation of each professional, which will have a positive effect on the general public's perception of the industry.
\end{abstract}

Keywords: Construction Industry, Construction Professional, Effective, Enforcement, Ethical Standards

\section{Introduction}

Ethics cover all sectors of the economy, construction industry inclusive. Ethics could be referred to as a set of principles which include social, religious or civil code of behaviour that is considered to be correct. Robinson, Dixon, Preece and Moodley (2007) defined ethics as the philosophical study of what is right or wrong in human conducts and what rules or principles should govern it. However, Loulakis (2003) perceived ethics to be the agreed set of principles for a particular profession linked to moral values held by a group or society at large. Naturally, truths should govern human nature from which one should be able to differentiate between what is right and wrong (Freeman, 2008). The naturally imbibed truths teach moral values and reject immoral values as unethical; the truths also referred to as professional ethics guiding professionals when discharging their duties. Professional

${ }^{1}$ Corresponding Author.

Email address: sjodediran@oauife.edu.ng ethics is the behaviour expected of an individual or a particular group in the industry that is bound by a set of principles, attitudes or types of character dispositions. These set of principles and attitudes control the way a profession is practiced (Vee \& Skitmore, 2003). Ethics, therefore, point to the standards or codes of behaviour expected by the group to which an individual belongs. This could be national ethics, social ethics, company ethics, even family or professional ethics (Kayne, 2010). Professional ethics are the moral values held by a group of people. This is peculiar to professions, in which the fundamental principles incorporated in their professional bodies include integrity, objectivity, competence and care, confidentiality and behaviour (Olatunji, Oke, Aghimien \& Ogunwoye, 2016). According to Lam, Hu, $\mathrm{Ng}$, Skitmore and Cheung (2001), the public expects the best from the professionals and the ethical conduct 
displayed by these professionals dictates how the society at large perceive such profession.

Various researchers have documented the ethical states of the construction industry. Oyewobi, Ganiyu, Oke, Ola-Awo and Shittu (2011) established that the industry has historically been challenged with severe pitfall in ethical conducts of construction professionals. Hence, the industry is susceptible to ethical erosion, probably due to its heterogeneous nature. Construction professionals are therefore not in the good books of private, corporate or public clients and this has attracted topical discourse than any other sector (Hong Kong Ethics Department Centre (HKEDC), 1996; Construction Industry Review Committee (CIRC), 2001; Hong Kong Housing Authority (HKHA), 2000; Ho and Ng, 2003). There have been several allegations concerning professional members of the construction industry involving both financial and professional misconducts which created concerns to the public. This led to a lack of trust and confidence of the public that require services of construction professionals and also at the receiving end (McCarty, 2012). The need for a mechanism to checkmate unethical practices is therefore necessary. Uff (2003) established that a mechanism to redeem the poor image of the industry is needed. Mason (2009) concluded that a single code could be fruitful when observed as part of broader measures for training and promoting ethical conduct in the construction industry. McCarty (2012) study was on developing an Australian code of construction ethics. The findings of the study revealed weaknesses which showed codes as remedial that might not provide any framework for decisions in the industry.

Despite measures put in place to safeguard the image of the industry, literature still revealed that the poor image of the industry, is due to the challenge in the enforcement of ethical standards. Based on the available findings from the literature, for the industry to remain in existence, a radical redemption of its image is then inevitable. The Nigerian construction industry, therefore, cannot afford to ignore the importance of professional ethics among the practitioners, which in recent years, has been documented to be under severe criticism (Alo, 2009). Despite seminars, workshops, sensitization and professional development programmes being organised by relevant professional bodies, the literature reveals that the poor image of the industry is due to the challenge in the enforcement of ethical standards which has attracted little attention in the literature. Hence, this study, therefore, examines the effectiveness of mechanisms for enforcement of ethical standards to mitigate ethical lapses and improve the image of construction professionals and the industry at large.

\section{Review of Literature}

\subsection{Ethical Conducts and Construction Professionals}

Ethical conducts among construction professionals had been of concern generally. Badger (1996) assessed the significance of ethical conduct among people working in the industry. It was concluded that professionals should interpret personal ethics as treating others with the same degree of honesty they would like to be treated. As important as professional ethics is in the construction industry, non-adherence to ethical standards can cause a major injury or at times lead to loss of life and even property. This implies that any unethical conduct which the professional is involved in has a direct and adverse effect on human lives (Davis, 2001). Personal ethics is therefore essential, which is believed to be a reflection of one's background, personality and values. Professionals' perspective to ethical conduct can be strongly influenced by the morals and values upheld by an organization in which a professional belongs. Irrespective of one's sense of doing what is right or wrong, professionals might be engulfed by the non-observance of professional ethics based on the employing organization. It was, therefore concluded that ethical problems could be directly traced to the organizational culture and leadership in the construction industry (Brien, 1998).

Unethical behaviour is an impediment to economic development and sustainable growth in any given society, especially in developing nations under which Nigeria is categorized (Ikuabe, 2015). Studies on unethical practices in the construction industry abound, and these include BMPIU (2005); Olatunji (2008); Ayangade, Wahab and Alake (2009) and Ameh and Ogundare (2013). The nature and peculiarities of construction activities at times give room for ethical dilemmas both at pre and post contract stages. Such activities include contract documentation, obtaining tenders, contract awards, contract administration, procurements of materials, valuation, and stage payments (Oyewobi et al., 2011). Whenever professionals are involved in any of these unethical practices, the reputation of the industry is questioned. Related studies identified bid-cutting, bid-shopping, hidden fees and commissions; and compensations as everyday acts that impinge on professional integrity and make clients lose their confidence in construction professionals (Zarkada-Fraser \& Skitmore 2000; May, Wilson \& Skitmore, 2001). Vee and Siktmore (2003) researched the use of ethical codes in the Australian construction industry. Findings revealed that the subject matter of ethics never cropped up in business meetings despite the use of ethical codes. Ethical issues were examined among construction managers, contractors and sub-contractors in the American construction industry. It was noted that 'reverse auctions' in the procurement process was perceived to be ethical by the American clients; however, this is considered to be unethical by the contractors (Doran, 2004).

Other related studies included identification of problems facing professional environment, which include quality control and how ethical matters are addressed in the organisations (Pearl, Bowen, Makanjee, Akintoye \& Evans, 2005). A comparative investigation of the relationship between professional ethics and construction quality in Australia and South Africa indicated that corruption, negligence, bribery, conflicts of interest, underbidding, cover pricing, and bid withdrawal affects the quality of construction services (Abdul-Rahman, Wang \& Yap, 2010). An appraisal of the ethical issues in the Kenyan construction industry with a particular focus on professional conduct in engineering technology management was investigated by Githui (2011). Findings from the study showed that achieving professionalism in 
the industry depends squarely on the moral and ethical nature of the industry's participants. It was thereby recommended that the main focus should be on espousing moral conduct in service delivery. Having examined studies on ethical issues in the construction industry globally, research findings established that what is obtainable in the Nigerian construction industry is similar to other countries. However, cases of misconducts among construction professionals are rampant in Nigeria (Oke, Aghimien \& Aigbavboa, 2017). It can, therefore, be concluded that studies on professional ethics in the construction industry abound, although few were recorded on effective mechanisms for the enforcement of ethical standards in Nigeria. This constitutes the focus of this study.

The state of corruption in the industry has warranted concerns from various stakeholders (Ameh \& Odusami, 2010a). Professional ethics in the Nigerian construction industry concerning clients' confidence and satisfaction were assessed (Olatunji, 2006). The study established a timely intervention for professionalism in order to avoid the collapse of the industry. Oyewobi et al. (2011) examined the determinants of unethical performance in the Nigerian construction industry. It was concluded that the industry is more susceptible to unethical problems because of the effect of corruption at the planning, tender and completion stages. Also, the study on Nigerian building professionals' ethical ideology and ethical judgement revealed that the current socio-political and economic situation in Nigeria affects the attitude and ethical practices of construction professionals (Ameh \& Odusami, 2010b). Ayodele, Ogunbode, Ariyo \& Alabi (2011) identified unethical practices in the Nigerian construction industry to include politics in the award of contract, societal corruption and quackery which is the involvement of non-professionals in the industry. The influence of unethical practices on management of construction projects in Nigeria was highlighted due to include the absence of punishment for corruption; loss of money due to change in government; lack of continuity in government programmes and availability of loopholes in project monitoring (Usman, Inuwa \& Iro, 2012). Also, Adeyinka, Jagboro \&Ojo (2016) investigated the level of usage of mechanism for enforcement of ethical standards. Findings concluded that specifically related mechanism was the most frequently used for enforcement of ethical standards. Construction professionals' compliance level with ethical standards was also examined, and results showed that construction professionals have fair compliance with ethical standards (Adeyinka, Jagboro, Ojo \& Odediran, 2014).

According to the reviewed related literature on professional ethics, it is quite clear that research on effective mechanisms for enforcement of ethical standards among construction professionals are limited. This is the main focus of the study. Identification of effective mechanisms will go a long way in assisting stakeholders in the construction industry, including the clients and the general public to tackle the menace of unethical conducts in the industry.

\section{Research Methodology}

The study was conducted in Lagos Metropolis on the premise that Lagos state is one of the states in Nigeria with the highest number of registered construction professionals in contracting and consultancy organisations. Also, $75 \%$ of construction firms in Nigeria are either based in Lagos State or have their branches located there (Fagbemi, 2008). The respondents included architects, builders, quantity surveyors, engineers (civil/structural, electrical, \& mechanical) estate surveyors, land surveyors and town planners. Data were collected through a questionnaire survey administered on professionals in the industry. Total of two hundred (200) copies of the questionnaire was administered randomly while 172 retrieved copies of questionnaires were found suitable for analysis. Section A of the questionnaire identified the background information of the respondents, while section $\mathrm{B}$ contained questions related to mechanisms for enforcement of ethical standards as identified from the literature. Professionals ranked the level of effectiveness of the identified mechanisms on a scale of $1-5$, where $5=$ most effective, $4=$ more effective, $3=$ effective, $2=$ less effective and $1=$ Not effective. Data collected were subjected to analysis using a relative effective index (REI) and Factor analysis. The use of relative effective index (REI) or index of relative importance/significance (RII) has been widely used in construction management researches (Adebowale \& Ojo, 2009; Ojo, 2010; Adeyinka, 2012, Opawole, 2015). REI was adapted from common relative index measurement, which is also described as relative importance index (RII) or relative significance index (RSI). In this study, it measures the relative index of effectiveness of mechanism for enforcement of ethical standards.

$R S I=\frac{\sum_{0}^{4} n_{i}-k_{i}}{n \times R_{h}}$

Where ni= number of respondent choosing

$k i=1-5$ on the Likert scale

$n=$ the total number of the questionnaire and;

$R h=$ the highest value in the ranking order.

Having determined REI of the mechanisms for enforcement of ethical standards, inferential statistics (factor analysis) was conducted to explore the attributes of the variables further and classified them. The extraction method of factor analysis was done through principal components analysis (PCA). PCA transforms original variables into a smaller set of the linear combination that represents the original set (Fellow and Liu, 2003). KaiserMeyer-Olkin Measure (KMO) and Barlett test of sphericity tests were also carried out to test the suitability of factor analysis data used.

\section{Result and Discussion}

The background information of the respondents sampled in the study and as presented in Table 1 indicate that $38.37 \%$ of the respondents are in the government organisations, $33.13 \%$ are in the contracting organisations while $28.48 \%$ are in consulting organisations. All the organizations were well represented in this survey from which information was gathered. The average year of the establishment of respondents' firms was approximately 18 years. Construction professionals surveyed included architects (20.30\%), builders (16.28\%), quantity 
surveyors $(18.02 \%)$, engineers $(19.18 \%)$, estate surveyors and valuers $(9.30 \%)$, land surveyors $(8.72 \%)$ and town planners $(8.14 \%)$. The result showed that different professionals and their diverse opinions on the research objectives would enrich the outcome of this study. Also, the result revealed that $86.04 \%$ had academic qualifications ranging from HND, PGD, B.Sc. and M.Sc.
Also, $86.63 \%$ of respondents surveyed are members of their respective professional association, and this indicates that respondents are professionally qualified and the average working experience of the respondents was 19 years. Having examined their particulars, it was clear that the information supplied by the respondents can be relied upon.

Table 1 Background information of respondents

\begin{tabular}{|c|c|c|c|}
\hline Profile & Parameters & Frequency & Percentage \\
\hline \multirow{3}{*}{ Type of Organization } & Consulting & 49 & 28.49 \\
\hline & Contracting & 57 & 33.14 \\
\hline & Government or public & 66 & 38.37 \\
\hline \multirow{6}{*}{$\begin{array}{l}\text { Years of Establishment of the Firms } \\
\text { (Mean=17.64 years) }\end{array}$} & $0-10$ years & 65 & 37.80 \\
\hline & $11-20$ years & 46 & 26.74 \\
\hline & 21-30 years & 32 & 18.60 \\
\hline & $31-40$ years & 14 & 8.14 \\
\hline & $40-49$ years & 12 & 6.98 \\
\hline & Above 50 & 3 & 1.74 \\
\hline \multirow{5}{*}{$\begin{array}{l}\text { Years of Work Experience of the } \\
\text { Respondents } \\
\text { (Mean }=18.61 \text { years) }\end{array}$} & $0-10$ years & 54 & 31.40 \\
\hline & $11-20$ years & 49 & 28.49 \\
\hline & $21-30$ years & 35 & 20.35 \\
\hline & $31-40$ years & 24 & 13.95 \\
\hline & $>40$ years and above & 10 & 5.81 \\
\hline \multirow{7}{*}{ Profession of the Respondents } & Architects & 35 & 20.35 \\
\hline & Builders & 28 & 16.28 \\
\hline & Quantity Surveyors & 31 & 18.02 \\
\hline & Engineers & 33 & 19.19 \\
\hline & Estate Surveyor & 16 & 9.30 \\
\hline & Land Surveyor & 15 & 8.72 \\
\hline & Town Planners & 14 & 8.14 \\
\hline \multirow{6}{*}{$\begin{array}{l}\text { Academic Qualification of the } \\
\text { Respondents }\end{array}$} & OND & 18 & 10.47 \\
\hline & HND & 37 & 21.51 \\
\hline & B.Sc./B.Tech. & 72 & 41.86 \\
\hline & PGD & 24 & 13.95 \\
\hline & M.Sc. & 15 & 8.72 \\
\hline & $\mathrm{PhD}$ & 6 & 3.49 \\
\hline \multirow{9}{*}{$\begin{array}{l}\text { Professional Qualifications of the } \\
\text { Respondents }\end{array}$} & Nigerian Institute of Architects & 31 & 18.02 \\
\hline & Nigerian Institute of Builders & 26 & 15.12 \\
\hline & Nigerian Institute of Quantity Surveyors & 28 & 16.28 \\
\hline & Nigerian Society of Engineers & 25 & 14.53 \\
\hline & Nigerian Institute of Estate Surveyors and Valuers & 14 & 8.14 \\
\hline & Nigerian Institution of Surveyors & 13 & 7.56 \\
\hline & Nigerian Institute of Town Planners & 12 & 6.98 \\
\hline & Non-Professionally Qualified & 23 & 13.37 \\
\hline & Total & 172 & 100.00 \\
\hline
\end{tabular}

\subsection{Effectiveness of Enforcement Mechanism}

The study examined the effectiveness of mechanisms for enforcement of ethical standards in the Nigerian construction industry. The respondents ranked 50 mechanisms identified from the literature, and the result is as presented in Table 2. From the Table, relative effective index (REI) values ranged between 0.525 and 0.585 . The result shows that all the mechanisms were ranked above average (0.5), signifying a moderate level of effectiveness of mechanisms used for enforcement of ethical standards. Some of these mechanisms for enforcement of ethical standards include commitments to personal reputation (REI=0.585). This is followed by promotion of civic right ( $R E I=0.582)$, good citizenry (REI $=0.581)$, constant checks and control (REI=0.580), disciplinary measures for misconducts (REI=0.580), good building process planning ( $\mathrm{REI}=0.578)$, sense of social responsibility $(\mathrm{REI}=0.578)$, individual willingness to comply (0.580), and personal ethical influence in the organisation $(\mathrm{REI}=0.577)$. Others are regular review of professional ethics (REI=0.569), implementation of national building codes (REI=0.568), good safety measures $(\mathrm{REI}=0.580)$, implementation processes by concerned authority (REI $=0.563)$, standardized \& universal procedures for individuals and accreditation (REI=0.561), continuing training for members in the industry (REI $=0.543)$, internal and external project monitoring (REI=0.543), conviction of offenders (REI=0.542), strict compliance with due process in tendering ( $\mathrm{REI}=0.542)$, protecting the industry image $(\mathrm{REI}=0.541)$ and roles of media houses $(\mathrm{REI}=0.539)$. 
Table 2: Relative effective index of mechanisms for the enforcement of ethical standards

\begin{tabular}{|c|c|c|}
\hline & Effective Mechanism & REI \\
\hline 1 & Personal reputation & 0.585 \\
\hline 2 & Promotion of civic right & 0.582 \\
\hline 3 & Good citizenry & 0.581 \\
\hline 4 & Constant checks and control & 0.580 \\
\hline 5 & Disciplinary measures for misconduct & 0.580 \\
\hline 6 & Good building process planning & 0.578 \\
\hline 7 & Sense of social responsibility & 0.578 \\
\hline 8 & Licensing regulation & 0.577 \\
\hline 9 & Personal ethical influence in the organisation & 0.577 \\
\hline 10 & Instilling self-regulation consciousness into members & 0.576 \\
\hline 11 & Conformity with codes of ethics & 0.576 \\
\hline 12 & Regulation of membership & 0.576 \\
\hline 13 & Ensuring compliance with industry best practices & 0.575 \\
\hline 14 & Keeping members informed of the latest operational procedures in the industry & 0.573 \\
\hline 15 & Individual willingness to comply & 0.570 \\
\hline 16 & Periodic review of processes of membership & 0.570 \\
\hline 17 & Regular review of professional ethics & 0.569 \\
\hline 18 & Implementation of national building codes & 0.568 \\
\hline 19 & Good safety measures & 0.567 \\
\hline 20 & Implementation processes by the concerned authority & 0.563 \\
\hline 21 & Standardized \& universal procedures for individual \& accreditation & 0.561 \\
\hline 22 & Investigation of petition & 0.560 \\
\hline 23 & Implementation of continuous professional development & 0.557 \\
\hline 24 & Constant reviewing of professional conducts \& standards & 0.556 \\
\hline 25 & Improving efficiency \& accountability & 0.555 \\
\hline 26 & Commitment to local community protection and engagement & 0.554 \\
\hline 27 & Withdrawing license of erring members & 0.552 \\
\hline 28 & Monitoring local industries producing building materials & 0.550 \\
\hline 29 & Protecting clients interest in the subject matter & 0.548 \\
\hline 30 & Ensuring employees follow compliance rule \& regulation & 0.546 \\
\hline 31 & Campaigning strict adherence to benchmark standards & 0.545 \\
\hline 32 & Sanctions on professional involved in misconducts & 0.545 \\
\hline 33 & Continuing training for members in the industry & 0.543 \\
\hline 34 & Internal \& external project monitoring & 0.543 \\
\hline 35 & Conviction of offenders & 0.542 \\
\hline 36 & Strict compliance with "Due process" in tendering activities & 0.542 \\
\hline 37 & Protecting the industry image & 0.541 \\
\hline 38 & Automatic alert of changes in laws and regulations & 0.540 \\
\hline 39 & Judicial courts & 0.540 \\
\hline 40 & Roles of media houses & 0.539 \\
\hline 41 & Viewing contract history for future reference & 0.538 \\
\hline 42 & Performing compliance risk assessment & 0.536 \\
\hline 43 & Virtual evidence room to link activities \& documents to related law & 0.533 \\
\hline 44 & Performing audits in case of disputes & 0.533 \\
\hline 45 & Transparency initiatives & 0.533 \\
\hline 46 & Anti-fraud \& Anticorruption crusade & 0.530 \\
\hline 47 & Managing all aspects of the contract via the internet & 0.530 \\
\hline 48 & Prosecution of offenders & 0.530 \\
\hline 49 & Automatic redlining to easily highlight changes during negotiation & 0.526 \\
\hline 50 & Emporium templates for a standard agreement & 0.525 \\
\hline
\end{tabular}

Where: Rk: Ranking and REI: Relative Significant

These mechanisms showcase the efforts of individual professionals in the enforcement of ethical standards in the construction industry. Nearly all the identified mechanism listed are achievable through the help of an individual professional which depicts that individual professional must have a sense of social responsibility to their clients. Social responsibility relevant to the construction industry includes a moral obligation to be a good citizen; sustainability; reputation; relationship with employees and unions; and relationship with suppliers and community representatives. The effectiveness of these mechanisms is, therefore subjected to the individual willingness to comply. Also, the roles of government agencies in the enforcement of ethical standards in the industry were identified. This means that if any of the mechanisms will be effective, government as enforcement agency should be firm and strict. It should also be noted that the roles of the industry in managing their activities 
are equally important. The least factors are managing all aspects of the contract via the internet, prosecution of offenders, automatic redlining to easily highlight changes during negotiations and enporion templates for standard agreement. The result shows the role of the industry with the technological challenges in the global world, where major contracts deals are carried out via the internet

\subsection{Principal Component Analysis (PCA)}

Factor analysis through Principal Components Analysis (PCA) test was carried out, and the results are shown in Table 3. Table 3 presented the result of the measure of sampling adequacy test, which was higher than 0.5 and KMO value of 0.970 . Bartlett's test of sphericity was highly significant $(X 2=1.956 \mathrm{E} 4, \mathrm{P}<0.05)$. This result implied that factor analysis carried out was suitable for data collected for this study. This conforms with Field (2005) submission that for factor analysis to proceed; the value of a set of scores should be closer to 1 . Also, considering the communalities of the variables, Field (2013) defined communality as a measure of the proportion of variance explained by the extracted factors. Having 30 variables or more gives communalities greater than 0.7 for all variables; however, less than 20 variables can have communalities less than 0.4 (Guadagnoli \& Velicer, 1988). Communalities after extraction are expected to be high to have a reasonable representation (Agbabiaka, 2016). From the result in Table 4, communalities are higher than 0.70 for all variables. The average communality after extraction is $0.844(84.4 \%)$, which further confirms the suitability and appropriateness of PCA. Table 5 presented the rotated component matrix, and total variance explained for factor groupings, respectively. Four components were identified with the first dominant factor accounting for $68.22 \%$ of the observed variance. The cumulative percentage of variance explained by the four mechanisms for enforcement was $84.39 \%$. This means that $84.39 \%$ of the common variance shared by 50 variables can be accounted for by four components. These components were grouped, labelled and presented in Table 5.

Table 3: KMO and Bartlett's Test

\begin{tabular}{lll}
\hline $\begin{array}{l}\text { Kaiser-Meyer-Olkin Measure of Sampling } \\
\text { Adequacy }\end{array}$ & .970 \\
\hline $\begin{array}{lll}\text { Bartlett's Test of } \\
\text { Sphericity }\end{array}$ & Approx. Chi-Square & $1.956 \mathrm{E} 4$ \\
\cline { 2 - 3 } & Df & 1225 \\
\cline { 2 - 3 } & Sig. & .000 \\
\hline
\end{tabular}

\subsection{Interpretation of Results}

Table 5 also shows the component factors (mechanisms) for enforcement of ethical standards and the loading items. Communalities of the variables loaded under each component factor ranged from 0.773 to 0.911 , which gives information about how much of the variance in each item is explained. The first mechanism was stakeholderrole related and accounted for $68.221 \%$ of the observed variance and followed by individual- related that accounted for $9.647 \%$, industry-related that accounted for $3.647 \%$ and legal instruments-related that accounted for $3.08 \%$.
Stakeholder-role related mechanism accounted for $68.22 \%$ of the observed variance with nineteen (19) loading items having high loading scores that ranged from 0.809 to 0.604 . Some of the items loaded with their loading scores include ensuring compliance to industry best practices (0.809), campaign for strict adherence to benchmark standards $(0.808)$ regulation of membership (0.804), keeping members informed of the latest procedures in the industry (0.790), withdrawing licence of erring members (0.798), and constant reviewing of professional conducts and standards (0.783). Others are instilling self-regulation consciousness into members (0.779), periodic review of processes of membership (0.771), implementation of continuous professional developments (0.768), standardised \& universal procedures for individuals and accreditation (0.761), monitoring local industries producing building materials $(0.723)$, roles of media houses $(0.727)$, protecting the industry image (0.722), internal and external project monitoring (0.720), and monitoring of national building codes (0.708). In addition to these are continuing training for members in the industry (0.708), strict compliance with due process in tendering activities (0.710), implementation of national building codes (0.652) and good building process planning (0.604).

The second component was the individual-related mechanism that accounted for $9.44 \%$ of the observed variance with fifteen (15) loading items having high loading scores that ranged from 0.840 to 0.767 . Items loaded were in conformity with codes of ethics (0.842), good safety measures (0.840), the good citizenry (0.839), commitments to local community protection engagement (0.832), sense of social responsibility (0.831) and licensing regulation $(0.825)$. In addition to these are personal reputations $(0.824)$, promotion of civic rights (0.822), regular review of professional ethics (0.821), disciplinary measures for misconduct $(0.818)$, protecting clients' interest in the subject matter (0.810), and individual willingness to comply (0.804). Others are a personal ethical influence in the organisation (0.805), implementation processes by concerned authority (0.797) and constant checks and control (0.767). Majority of the items loaded under this factor emanated mainly from personal and individual attributes of the professional.

The third component was an industry-related mechanism which accounted for $3.64 \%$ of the observed variance with ten (10) loading items having high loading scores that ranged from 0.746 to 0.689 . These include virtual evidence room to link activities and documents to related laws (0.746), ensuring employees follow compliance rule and regulation $(0.745)$, viewing contract history for future reference (0.744), enporion templates for standards agreement (0.732), automatic alert of changes in laws and regulations (0.732). Others were improving efficiency and accountability (0.725), managing all aspects of the contract via the internet (0.724), performing a compliance risk assessment (0.715), performing audits in case of disputes (0.700) and automatic red linning function to easily highlight change during negotiation (0.689). It was noted that all these items indicated the roles of the industry in enforcements of ethical practices. 
The fourth component was the legal instruments-related mechanism that accounted for $3.08 \%$ of the observed variance with six (6) loading items having high loading scores that ranged from 0.737 to 0.691 . These include prosecution of offenders (0.737), anti-fraud and anti- corruption crusade (0.729), investigation of the petition (0.722), the conviction of offenders (0.715), transparency initiatives (0.701) and judicial courts (0.691) - all these items related to a legal instrument of ethical enforcement.

Table 4: Communalities before and after

\begin{tabular}{|c|c|c|c|}
\hline S/no & Variables & Initial & Extraction \\
\hline 1. & Promotion of civic right & 1.000 & .825 \\
\hline 2. & Sense of social responsibility & 1.000 & .842 \\
\hline 3. & Good citizenry & 1.000 & .826 \\
\hline 4. & Personal reputation & 1.000 & .773 \\
\hline 5. & Good safety measures & 1.000 & .821 \\
\hline 6. & Commitment to local community protection and engagement & 1.000 & .819 \\
\hline 7. & Constant checks and control & 1.000 & .783 \\
\hline 8. & Licensing regulation & 1.000 & .847 \\
\hline 9. & Conformity with codes of ethics & 1.000 & .866 \\
\hline 10. & Disciplinary measures for misconduct & 1.000 & .823 \\
\hline 11. & Regular review of professional ethics & 1.000 & .851 \\
\hline 12. & Protecting clients interest in the subject matter & 1.000 & .838 \\
\hline 13. & Individual willingness to comply & 1.000 & .828 \\
\hline 14. & Implementation processes by the concerned authority & 1.000 & .815 \\
\hline 15 . & Personal ethical influence in the organization & 1.000 & .839 \\
\hline 16. & Investigation of petition & 1.000 & .881 \\
\hline 17. & Conviction of offenders & 1.000 & .874 \\
\hline 18. & Prosecution of offenders & 1.000 & .885 \\
\hline 19. & Anti fraud \& Anticorruption crusade & 1.000 & .892 \\
\hline 20. & Transparency initiatives & 1.000 & .854 \\
\hline 21. & Judicial courts & 1.000 & .844 \\
\hline 22. & Good building process planning & 1.000 & .784 \\
\hline 23. & Implementation of national building codes & 1.000 & .825 \\
\hline 24. & Monitoring local industries producing building materials & 1.000 & .853 \\
\hline 25. & Continuing training for members in the industry & 1.000 & .790 \\
\hline 26. & Sanctions on professional involved in misconducts & 1.000 & .818 \\
\hline 27. & Strict compliance to "Due process" in tendering activities & 1.000 & .843 \\
\hline 28. & Internal \& external project monitoring & 1.000 & .819 \\
\hline 29. & Roles of media houses & 1.000 & .823 \\
\hline 30. & Protecting the industry image & 1.000 & .833 \\
\hline 31. & Instilling self-regulation consciousness into their members & 1.000 & .853 \\
\hline 32. & Regulation of membership & 1.000 & .866 \\
\hline 33. & Ensuring compliance with industry best practices & 1.000 & .862 \\
\hline 34. & Constant reviewing of professional conducts \& standard & 1.000 & .845 \\
\hline 35 . & Withdrawing license of erring members & 1.000 & .815 \\
\hline 36. & Campaigning strict adherence to benchmark standards & 1.000 & .885 \\
\hline 37. & Implementation of continuous professional development & 1.000 & .804 \\
\hline 38. & Periodic review of processes of membership & 1.000 & .815 \\
\hline 39. & Keeping members informed of the latest operational procedures in the industry & 1.000 & .847 \\
\hline 40. & Standardized \& universal procedures for individual \& accreditation & 1.000 & .845 \\
\hline 41. & Improving efficiency \& accountability & 1.000 & .858 \\
\hline 42. & Ensuring employees follow compliance rule \& regulation & 1.000 & .874 \\
\hline 43. & Automatic alert of changes in laws and regulations & 1.000 & .879 \\
\hline 44. & Performing compliance risk assessment & 1.000 & .877 \\
\hline 45 . & Virtual evidence room to link activities \& documents to related law & 1.000 & .890 \\
\hline 46. & Performing audits in case of disputes & 1.000 & .893 \\
\hline 47. & Viewing contract history for future reference & 1.000 & .894 \\
\hline 48. & Enporion templates for a standard agreement & 1.000 & .911 \\
\hline 49. & Managing all aspects of the contract via the internet & 1.000 & .846 \\
\hline 50. & Automatic red linning function to easily highlight changes during negotiation & 1.000 & .824 \\
\hline
\end{tabular}


Table 5: Factor loadings and Total Variance explained of Effectiveness of Mechanism for Enforcement of Ethical Standards

\section{Components \\ Components}

Factor
Loadings

$\%$ of the \% of the total

Stakeholder-role related

Good building process planning

34.111

total

variance

cummulative

Implementation of national building codes

.604

.652

$\begin{array}{ll}\text { Monitoring local industries producing building materials } & .723\end{array}$

$\begin{array}{ll}\text { Continuing training for members in the industry } & .708\end{array}$

$\begin{array}{ll}\text { Sanctions on professional involved in misconducts } & .708\end{array}$

Strict compliance with "Due process" in tendering activities $\quad .710$

Internal \& external project monitoring $\quad .720$

$\begin{array}{ll}\text { Roles of media houses } & .727\end{array}$

$\begin{array}{ll}\text { Protecting the industry image } & .722\end{array}$

$\begin{array}{ll}\text { Instilling self-regulation consciousness into members } & .779\end{array}$

$\begin{array}{ll}\text { Regulation of membership } & .804\end{array}$

Ensuring compliance with industry best practices $\quad .809$

Constant reviewing of professional conducts \& standard $\quad .783$

Withdrawing license of erring members $\quad .781$

Campaigning strict adherence to benchmark standards $\quad .808$

Implementation of continuous professional development $\quad .768$

Periodic review of processes of membership $\quad .771$

Keeping members informed of the latest operational procedures in the $\quad .790$

industry

Standardized universal procedures for individual \& accreditation

\begin{tabular}{ll}
\hline Individual-related & .761 \\
Promotion of the civic right & .822 \\
Sense of social responsibility & .831 \\
Good citizenry & .839 \\
Personal reputation & .824 \\
Good safety measures & .840 \\
Commitment to local community protection and engagement & .832 \\
Constant checks and control & .767 \\
Licensing regulation & .825 \\
Conformity with codes of ethics & .842 \\
Disciplinary measures for misconduct & .818 \\
Regular review of professional ethics & .821 \\
Protecting clients interest in the subject matter & .810 \\
Individual willingness to comply & .804 \\
Implementation processes by the concerned authority & .797 \\
Personal ethical influence in the organisation & .805 \\
\hline Industry-related &
\end{tabular}

Industry-related
Improving efficiency \& accountability

$\begin{array}{ll}\text { Ensuring that employees follow a compliance rule and regulation } & .725\end{array}$

$\begin{array}{ll}\text { Automatic alert of changes in laws and regulations } & .731\end{array}$

Performing compliance risk assessment $\quad .715$

Virtual evidence room to link activities \& documents to related law $\quad .746$

Performing audits in case of disputes $\quad .700$

$\begin{array}{ll}\text { Viewing contract history for future reference } & .744\end{array}$

Enporion templates for a standard agreement $\quad .732$

$\begin{array}{ll}\text { Managing all aspects of the contract via the internet } & .724\end{array}$

\begin{tabular}{ll} 
Automatic red linning function to easily highlight changes during negotiation $\quad .689$ \\
\hline
\end{tabular}

\begin{tabular}{lll}
\hline Legal-instruments related & .689 & 3.084 \\
Investigation of petition & .722 & 84.396 \\
Conviction of offenders & .715 & \\
Prosecution of offenders & .737 \\
Anti fraud \& Anticorruption crusade & .729 \\
Transparency initiatives & .701 \\
Judicial courts & .691 \\
\hline
\end{tabular}

Extraction Method: Principal Component Analysis. Rotation Method: Varimax with Kaiser Normalization. Rotation converged in six iterations. 


\subsection{Discussion of Findings}

The results of REI on the effectiveness of mechanisms for enforcement of ethical standards revealed highly ranked mechanism for enforcement of ethical standards to include commitments to local protection and engagement, personal reputation, good citizenry, individual willingness to comply, good safety measures and promotion of civil rights. Others included withdrawing license from erring members and conviction of offenders. These mechanisms were also highly loaded by principal component analysis (PCA). These mechanisms originated from individuals, which re-emphasises that the effectiveness of any mechanisms can be achieved and be fruitful through the commitments of the individual professional. This calls for the sense of social responsibility from all the stakeholders in the industry. The result affirmed the assertion that professionals must have a sense of social responsibility to their clients and companies should develop corporate social responsibility (CSR) in order to maintain an image of being a good corporate citizen (Petrovic-Lazarevic, 2008). Social responsibilities relevant to the construction industry include moral obligation to be a good citizen, sustainability, reputation, relationship with employees and unions.

The results from factor analysis identified four effective mechanisms for enforcement of ethical standards. The first one was stakeholder-role relatedmechanism. Items loaded under this component included instilling self-regulation consciousness into members, ensuring compliance to industry best practices, regulation of membership, implementation of national building codes and implementation of continuous professional developments. Others were good building process planning and monitoring of national building codes. Least items under this factor were continuing training for members in the industry, withdrawing license from erring members. This mechanism and the loading items indicated the combination of governments' legislation and professional bodies' roles in combating corruption in the construction industry. All stakeholders must work together to sanitize and change the public perception about the industry. This can be achieved through the implementation of code of ethics, conduct and practice. Construction stakeholders like government are saddled with the responsibilities of enforcing ethical standards among practitioners through the establishment of code of practice which can be living documents through implementation by the government (Ho and $\mathrm{Ng}, 2003$ ). The findings corroborated Ladd (1991) that code of conduct includes principles, values, standards, or rule of behaviour guiding decisions, procedures and systems of an organisation in a way that contributes to the welfare of the stakeholders and respects the right of all individuals affected by its operations. Through this, the profession is regulated while the responsibilities of professionals are spelt out clearly. This also affirmed Vee and Skitmore (2003) that a clearer picture of behaviour considered ethical, correct or right are provided through code of conduct. Effective mechanisms for enforcements of ethical standards included implementation of national building codes, good building process planning, monitoring local industries that are producing building materials and strict compliance to "due process" in tendering activities. This is in agreement with Nduese (2010) that curbing the incidence of collapsed buildings must involve the implementation of 2005 National Building Codes. If these codes are implemented, it will take care of building materials and specifications used. Implementation involves following good building planning process as well as compliance with due process in all contract processes, which reduces unethical conducts. Also, the roles of professional associations cannot be underrated. Professional bodies are to make professional developments compulsory for all the members, and this can be achieved through conferences, seminars and workshops. Also, professional bodies should be firm in withdrawing the license of the erring members, which will make other professionals that wish to defaults to decline from unethical practices. Findings agreed with Sohail and Cavil (2008) that professional associations have a critical role in regulating the conduct of her members. Besides, all construction stakeholders should exhibit the hallmark of professional excellence through adherence to ethics, values, competence and integrity (Usman et al., 2012).

The second component was individual-related mechanism and items loaded under this mechanism included commitments to local community protection and engagement, personal reputation, good citizenry, good safety measures and individual willingness to comply. Others are a sense of social responsibility and implementation by the concerned authority. These items were expected to be loaded high because no amount of laid down regulations will yield positive results if concerned personality is unwilling to comply. Items loaded under this mechanism originated from personal and individual factors which affect the moral behaviour of professionals. This conformed with Ukoha (2004) that values influences man's choice and have a significant effect on his behaviour, which is traceable to the background and upbringing of an individual. As strong as ethical codes are, their success lies in the personality's willingness to comply with the principles espoused in the codes. Codes are not strong enough to alter behaviours themselves except personality concerned (Allen \& Davis, 1993). Nduka (2004) argued that personality is expressed in the form of values, desires, interests, goals, approvals/disapprovals, preferences and standards. The civic right is promoted when professionals possess good personal reputation. Professionals should note their actions influence the life of others, the environment and the general public. Values, therefore, occupy a central position in all human endeavours and form the basis for social interaction in every society. Human survival depends mostly on their roles in transmitting essential value patterns to the incoming generations (Gibson, 2011). Conclusively, on this component, the issue of personal responsibility cannot be ruled out in enforcing ethical standards. Personal responsibility of professionals should be the foundation as well as the sustenance of ethical standards in the industry.

The third component was an industry-related mechanism with items such as performing audits in case of disputes, automatic alert, ensuring employees comply with the rules and regulations of changes in law and 
regulation, virtual evidence room to link activities and documents to related laws. Other mechanisms are an automatic red linning function to easily highlight changes during the negotiation and managing all aspects of the contract via the internet. These mechanisms generated from compliance software programmes used in construction industries for enforcement of ethical practices is technology-based and also expensive. The result indicates the roles of the industry in enforcements of ethical practices. The industry should ensure relevant software in construction-related fields is available to enable the professionals to perform optimally. Also, the industry should create awareness for their employees to operate and exert a strong influence on the ways professionals obliged to conduct their affairs in contemporary society. Findings supported Lawton (2005) that organisations have duties to their employees regarding their concerns for the public interest. The ethical orientations of organisations should be based on the interests and needs of clients. Furthermore, the industry should be current and well equipped always to be relevant with the latest technological advancement in meeting clients' expectations and needs, especially in this fast-growing technological age.

The fourth component for enforcements of ethical standards was legal-instruments' related-mechanism. Items loaded under this include conviction of offenders investigation of petition, anti-fraud and anti-corruption crusade, prosecution of offenders and judicial courts, and transparency initiatives. Employing legal instruments related factor reduces unethical practices because lack of punishment for individuals involved in corruption is one of the factors influencing unethical practices (Usman et al., 2012), and leading to different anomalies in the construction industry (Githui, 2011 \& Ayodele et al., 2011). These might question the effectiveness of regulatory agencies in curbing corruption and related financial offences. Functions of these agencies include receiving, investigating petitions, and prosecute the

\section{References}

Abdul-Rahman, H, Wang, C. \& Yap, X.W. (2010). How Professional Ethics Impact Construction Quality; Perception and Evidence in a Fast Developing Economy" Scientific Research and Essays, 5(23), 3742-3749.

Adebowale, O.F. \& Ojo, G.K. (2009). Validating the Relative Effective Index (REI) in Counseling and Educational Survey Researches: Prevalent Online Counseling Needs of Students in a Nigerian University. Ife Journal of Theory and Research in Education, 12(1), 119-130.

Adeyinka, B.F. (2012). An Appraisal of Professional Ethics in the Nigerian Construction Industry. Unpublished M.Sc Thesis, Department of Quantity Surveying, Faculty of Environmental Design and Management, Obafemi Awolowo University, Ile-Ife, Nigeria.

Adeyinka, B.F., Jagboro G.O., Ojo G.K. \& Odediran, S.J. (2014). An Assessment of Construction Professionals' Level of Compliance to Ethical Standards in the Nigerian Construction Industry. Journal of Construction Project Management and Innovation, 4(1), 863-881. offenders in appropriate cases. Also, they advise the government and educate the public and thereby foster their supports against corruption (Ajibola, 2006). Based on the research findings, legal-instruments related factor was the least component for enforcement of ethical standards. Legal instruments may only be effective in combating unethical practices in the construction industry if they are put in place and justices are administered fearlessly. Appropriate actions should be taken when unethical practices occur irrespective of the personality involved in which the rule of law should not be a respecter of persons. The menace of unethical practices in the industry can be curbed through the effective application of legal instruments that serve as deterrents to others. Also, the sector should be bold to convict offenders, and no individual should be considered to be above the law. A very weak legal framework, tainted judiciary and collapsed system of administration will not make the construction industry win the battle of corruption. Instead, a firm and brunt justice system is required.

\section{Conclusion and Recommendations}

This paper assessed the effective mechanisms for enforcement of ethical standards in the Nigerian construction industry. It was concluded that the impact of stakeholders, individuals, industry and the rule of law are effective mechanisms for enforcement of ethical standards. The study thereby recommends that government should focus on the implementation of ethical codes in professional practices whereby construction professionals perceive acting ethically as obligations. Construction stakeholders must collaborate to sanitize the image of the industry so that the already established codes will not only be on paper but rather become living documents that will be valued and respected by construction professionals.

Adeyinka, B. F., Jagboro G.O. \& Ojo G.K. (2016). Enforcement Mechanisms of Ethical Standards among Nigerian Construction Professionals. Journal of Environmental Design and Management, 8 (1\& 2), 24-37.

Agbabiaka, H. I. (2016). Physical planning implication of Eyo festival in Lagos Island, Nigeria, Cogent Social Sciences, 2, 1-14.

Ajibola, B.(2006). Restitution: An Alternative Solution to the Corruption Issue. A Paper presented at the Nigerian Institute of Town Planners, Airport Hotel, Ikeja Lagos, August 9.

Allen, J. \& Davis, D. (1993). Assessing Some Determinant Effects of Ethical Consulting Behavior: The Case of Personal and Professional Values. Journals of Business Ethics, 12(6), 49-459.

Alo, O. T. (2009). A Comparative Analysis of the Ethical Performances of Quantity Surveyors in the Public and Private Sectors in Nigeria. Unpublished B.Tech Thesis, Department of Quantity Surveying, Federal University of Technology, Akure, Nigeria.

Ameh, O. J. Odusami, K.T. \& Achi, F.O. (2007). An Assessment of Professional Ethics Content in the Academic Curriculum of Construction Discipline in 
Nigerian Universities. Built Environment Education Conference, 1-10.

Ameh, O. J. \& Odusami, K.T.(2010a). Professionals' Ambivalence Toward Ethics in the Nigerian Construction Industry. Journal of Professional Issues in Engineering Education and Practice, 136(1), 9-16.

Ameh, O. J. \& Odusami, K.T. (2010b). Nigerian Building Professionals' Ethical Ideology and Perceived Ethical Judgment. Australasian Journal of Construction Economics and Building, 10 (3), 1-13.

Ameh, O.J. \&Ogundare, O.(2013). Impact of Due Process Policy on Construction Project Delivery in Nigeria. Journal of Building Performance, 4(1), 13-23.

Ayangade, J.A., Wahab, A.B. \& Alake. O. (2009). An Investigation of the Performance of Due Process Mechanisms in the Execution of Construction Projects in Nigeria. Civil Engineering Dimensions, 11(1), 1-7.

Ayodele, E.O., Ogunbode, A.B., Ariyo, I.E. \& Alabi, O.M.(2011). Corruption in the Construction Industry of Nigeria; Causes and Solution. Journal of Emerging Trends in Economics and Management Sciences, 2(3), 156-159.

BMPIU, (2005). A Manual on Public Procurement Reform Programme in Nigeria, Due Process Office Publication, Second Edition, State House Abuja, Nigeria.

Badger, W.W. and Gay, S.W. (1996). The Top Ten Lessons Learned in Construction Contracting. Cost Engineering, 38(5) 20-9.

Brien, A.(1998). Professional Ethics and the Culture of

Trust. Journal of Business Studies, 1(17), 391-409.

Construction Industry Review Committee (CIRC)(2001). Construct for Excellence: Report of the Construction Industry Review Committee, Hong Kong.

Davis, I. (2001). Health and Safety, An Economic and Moral Issue. Master Builder, The Magazine of the Federation of Master Builders, March, 17.

Doran, D. (2004).FMI/Construction Management Associations of America (CMMA) Survey of Construction Industry Ethical Practices. [online]. http://www.acce-

hq.org/documents/ethics_survey.pdf.(March 2011).

Fagbemi, A. O. (2008). Assessment of Quantity Surveyors' Service Quality in Lagos State, Nigeria. Unpublished M.Tech. Thesis, Department of Quantity Surveying, Federal University of Technology, Akure, Nigeria.

Freeman, M.D.A. (2008).Introduction to Jurisprudence, Sweet and Maxwell.

Fellow, R. and Liu, A. (2003). Research Methods for Construction, 2nd Edition, Oxford: Blackwell Science Publishing Company.

Field, A.P.(2005). Discovering Statistics Using SPSS,

2nd Edition. London: Sage Publications.

Field, A.P. (2013). Discovering Statistics Using SPSS, 4th Edition. London: Sage Publications.

Gibson,J.(2011).Jackson GIBSON Construction Company [online]. Available from: wwwjackgibsonconstruction.com/safety.aspstates(Accessed April 2011).

Githui, D.M. (2011). Mobile Money Transfer in Kenya, An Ethical Perspective. Research Journal of Finance and Accounting, 2(2) [online]. Available from:
https://www.iiste.org/Journals/index.php/RJFA/article/vi ew/191. (Accessed June 25 2019).

Guadagnoli, E., \& Velicer, W. F. (1988). Relation of Sample Size to the Stability of Component Patterns, Psychological Bulletin, 103(2), 265-275.

Hong Kong Ethics Department Centre (HKEDC) (1996). Ethics from Professionals (Architecture, Engineering and Surveying). A Resource Portfolio for Hong Kong Universities. HKEDC, Hong Kong.

Hong Kong Housing Authority (HKHA)(2000). Quality Housing: Partnership for Change Consultative Document, Hong Kong.

Ho, M.F.N \& Ng, C.W.V. (2003).Quantity Surveyors' Background and Training and Their Ethical Concepts, Conception and Interests Considerations. Construction Management Economics, 21, 43 - 67.

Ikuabe, M. O. (2015). Unethical Practices and Construction Project Cost Performance in Nigeria. In: Ogunsemi, D.R., Awodele, O.A \& Oke, A.E. (Eds). Proceedings of the 2nd Nigerian Institute of Quantity Surveyors Research Conference, Federal University of Technology, Akure, Nigeria, 1st-3rd September 2015, 622-628.

Kayne, R.(2010).What is the Difference Between Ethics and Morals.[online]. http://www.wisegeek.com/what-is-the-differencebetween-ethics-and-morals.htm(25 May 2011).

Ladd, J. (1991). The Quest for a Code of Professional Ethics: An Intellectual and Moral Confusion In: Johnson, D.G. (Ed.) Ethical issues in Engineering, New Jersey.

Lawton, A. (2005). Public Services Ethics in a Changing World Future: Leadership in Construction Project. International Journal of Quality \& Reliability. [online]. Available from:www2 hull.ac.uk>HUBS home > About us > Our staff (Accessed March 18 2011).

Lam, K.C, Hu, T., Ng, S.T., Skitmore, M. \& Cheung, S.O. (2001). A Fuzzy Neural Network Approach for Contractors Prequalification. Construction Management and Economics, 19, 175 -188.

Loulakis, M. (2003) Ethics in Construction: Challenges and Dilemmas, International Risk Management Institute (USA) 18 Nov 2003.

May, D., Wilson, O.J. \& Skitmore, R.M.(2001). Bid Cutting: An Empirical Study of Practice in South East Queensland, Construction, Engineering and Architectural Management, 8(4), 250-256.

Mason, J. (2009). Can a Single Code for Professionals Promote Ethical Improvement in the Construction Industry? FIG Working Week 2011, Bridging the Gap between Cultures, Marrakech, Morocco, 18-22 May.

McCarty, S.F.(2012). Developing an Australian Code of Construction Ethics. Australian Journal of Construction Economics and Building, 12(2), 87-100.

Ukoha, (2004), Curriculum Development, Owerri, Totan Publishers.

Nduka, O.N.(2004). Values of Education. In: Oderinde, B. B. and Ekpo, O. (Ed.) Nigeria Academy of Education.

Nduese, E. (2010). Cement Producer, Builders Seek Solutions to Building Collapse". Peoples Daily, December 1, 2010. [online].www.peoplesdailyonline.com/.../1120-cement-producers-builders-seeksolutions-to-building-collapse. (Accessed April 26 2011). 
Ojo, G.K. (2010). An Assessment of Impact of Risk and Uncertainties on Construction Clients' Cash Flow Forecast in Selected Locations in Nigeria. Unpublished PhD Thesis, Department of Quantity Surveying, Faculty of Environmental Design and Management, Obafemi Awolowo University, Ile-Ife, Nigeria.

Oke, A.E., Aghimien, D.O. \& Aigbavboa, C.O. (2017). Effect of Code of Ethics on Quantity Surveying Practices in Ondo State, Nigeria, In: Ibrahim, Y., Gambo, N. and Katun, I. (Eds). Proceedings of the 3rd Research Conference Nigerian Institute of Quantity Surveyors, Abubakar Tafawa Balewa University, Bauchi, 25th-27th September 2017, 144-155.

Olatunji, O. A. (2006). Assessing Client's Confidence and Satisfaction in Construction Professionals in Nigeria. Proceedings of International Conference on Construction Culture, Innovation and Management, British University, Dubai, United Arab Emirate, 17-18 November 2006, 436445.

Olatunji, O.A.(2008). Due Process and Contractor Selection for Public Works in Nigeria. [online] Building Abroad, Procurement of Construction and Reconstruction Projects in the International Context, Montreal, Canada, 385-395 [online]. Available from: https://www.researchgate.net/publication/307248976_Du e_process_and_contractor_sele...(Accessed June 25 2019).

Olatunji, S.O., Oke, A. E., Aghimien, D. O. \& Ogunwoye, O.S. (2016). Implementation of the Code of Ethics among Quantity Surveying Firms in Nigeria. Developing Country Studies 6(5), 71-76.

Opawole, A. (2015). Assessment of Parties Obligations in Concession-Based Projects in South-Western Nigeria. Unpublished PhD Thesis, Department of Quantity Surveying, Faculty of Environmental Design and Management, Obafemi Awolowo University, Ile-Ife.
Oyewobi, I.O., Ganiyu, B.O., Oke, A.A., Ola-Awo, W. \& Shittu, A.A. (2011). Determinants of Unethical Performance in the Nigerian Construction Industry. Journal of Sustainable Development, 4(4), 175-182.

Pearl, R., Bowen, P., Makanjee, N., Akintoye, A. \& Evans, K. (2005). Professional Ethics in the South African Construction Industry: A Pilot Study. Journal of Construction Management and Economics, 25(6) 631648.

Petrovic-Lazarevic, S. (2008).The Development of Corporate Social Responsibility in the Australian Construction Industry. Construction Management \& Economics, 26(2), 93-101.

Robinson, S., Dixon, J.R., Preece, C.N. \& Moodley, K. (2007). Engineering, Business and Professional Ethics, Butterworth-Heinemann, Oxford.

Sohail, M. \& Cavil, S. (2008). Accountability to Prevent Corruption in Construction Projects. Journal of Construction Engineering and Management, 134, 729738.

Usman, N. D., Inuwa, I. I. \& Iro, A. I. (2012). The Influence of Unethical Professional Practices on the Management of Construction Projects in North Eastern States of Nigeria. International Journal of Economic Development Research and Investment, 3(2), 124-129.

Uff, J. (2003). Duties at the Legal Fringe: Ethics in Construction Law. Centre of Construction Law \& Management-The Michael Foundation fourth public lecture, The Great Hall, Kings College London, 19th June.

Zarkada-Fraser, A. \& Skitmore, R.M. (2000). Decisions with Moral Content: Collusion. Construction Management and Economics, 18(1), 101-11.

Vee, C. \& Skitmore, M. (2003). Professional Ethics in the Construction Industry. Engineering, Construction and Architectral Management, 19(21), 117-127. 